Authors: M Kersop and SF du Toit

\title{
ANTI-MONEY LAUNDERING REGULATIONS AND THE EFFECTIVE USE OF MOBILE MONEY IN SOUTH AFRICA - PART 1
}

\section{eISSN 1727-3781}

2015 VOLUME 18 No 5 


\title{
ANTI-MONEY LAUNDERING REGULATIONS AND THE EFFECTIVE USE OF MOBILE MONEY IN SOUTH AFRICA - PART 1*
}

\author{
M Kersop**
}

SF du Toit ${ }^{* * *}$

\section{$1 \quad$ Introduction}

Mobile technology ${ }^{1}$ affects the lives of billions of people worldwide ${ }^{2}$ and has transformed the way in which not only communication but also business transactions take place. $^{3}$ It is a valuable medium and a crucial piece of infrastructure which supports a number of economic sectors. ${ }^{4}$ In terms of financial services, ${ }^{5}$ the development of mobile technology has shown unique opportunities and allowed almost three billion people without bank accounts to gain access to financial services. ${ }^{6}$ This is a significant achievement, since the sparse availability of financial services is one of the most prominent restrictions on economic development. ${ }^{7}$ While this is a worldwide phenomenon, it is particularly true for rural areas in Sub-Saharan Africa, ${ }^{8}$ where low-income individuals have restricted access to traditional financial systems. ${ }^{9}$ Exclusion from the financial system is also one of the most substantial obstacles preventing the eradication of poverty. ${ }^{10}$

This article (in two parts) is based on M Kersop's mini-dissertation with the same title, submitted in partial fulfilment of an LLM in Import and Export Law at the Potchefstroom campus of the North-West University, prepared under the supervision of Prof SF du Toit.

** Marike Kersop. LLB LLM (NWU). Prosecutor, NPA and former LLM student, North-West University. Email: marike.kersop@gmail.com.

*** Sarel Francois du Toit. BA LLB LLD (RAU). Professor of Law, North-West University. Email: sarel.dutoit@nwu.ac.za.

1 The term "mobile technology" will be used as the collective term for mobile phones and mobile services.

2 Chatain et al World Bank Working Paper No 146 (hereafter referred to as World Bank Working Paper No 146) xiii, $1 . \mathrm{i}$

3 Jobodwana 2009 JICLT 287; World Bank Working Paper No 146 xiii.

4 Such as commerce, health insurance, banking and agriculture, among others: Lyons et al SubSaharan Africa Mobile Observatory 57.

5 The term "financial services" will be used as a collective term for facilities such as savings accounts and money transfers generally provided by banks, credit unions, and finance companies. See BusinessDictionary.com $2014 \mathrm{http}: / /$ www.businessdictionary.com/definition/ finan-cialservices.html\#ixzz3I5Sdfxj7.

$6 \quad$ World Bank Working Paper No 1461.

Lyons et al Sub-Saharan Africa Mobile Observatory 58.

Lyons et al Sub-Saharan Africa Mobile Observatory 58.

A financial system can be described as a system that allows the transfer of money between investors and borrowers. It comprises a set of closely interconnected financial institutions, 
Financial inclusion, which can be defined as "ensuring access to appropriate financial products and services at an affordable cost in a fair and transparent manner", ${ }^{11}$ has therefore become an increasingly important international policy initiative in the fight against poverty. ${ }^{12}$ This entails providing financially excluded individuals ${ }^{13}$ such as low-income, rural and undocumented persons who often have no other option than making do with cash and physical assets, ${ }^{14}$ with access to a sufficient variety of convenient, secure and inexpensive financial services. ${ }^{15}$ It also entails providing individuals who have access to only rudimentary financial services with a more extensive variety of financial services. ${ }^{16}$

Increased financial inclusion can be achieved by means of mobile money, which enables the storage of monetary value on a mobile phone. ${ }^{17}$ This stored value can be used to make payments or purchases or it can be sent to other mobile money users. ${ }^{18}$ Mobile money can be redeemed for cash $^{19}$ and cash can be converted into mobile money by depositing ${ }^{20}$ it into a mobile money account. ${ }^{21}$ Mobile money

markets, instruments, services, practices, and transactions. See O'Sullivan and Sheffrin Economics 551; Gurusamy Financial Services 3. Factors that prevent access to financial systems include high service costs, the geographic inaccessibility of bank branches and ATMs, and the negative perceptions of financial service providers.

10 The reason being that the lack of financial instruments such as accounts places a limitation on the ability of businesses and consumers to save, repay debts and manage risk. See Lyons et al Sub-Saharan Africa Mobile Observatory 58.

11 Financial inclusion is sometimes also simply defined as providing access to financial services for all. See FATF Guidance: Anti-Money Laundering and Terrorist Financing Measures and Financial Inclusion (2013) para 17 (hereafter referred to as FATF Guidance: AML and Financial Inclusion).

12 De Koker 2011 JFC 362.

13 FATF Guidance: AML and Financial Inclusion para 17. "Financial exclusion" will be used as the opposite of "financial inclusion", ie individuals who fall outside of a financial system and are in need of financial inclusion are currently financially excluded.

14 Alexandre and Eisenhart 2013 WJLTA 288; Jenkins Developing Mobile Money Ecosystems 5. Dealing with cash has inherent risks and costs which are excluded or at least mitigated by financial inclusion.

15 FATF Guidance: AML and Financial Inclusion para 17.

16 FATF Guidance: AML and Financial Inclusion para 17.

17 World Bank Working Paper No 146 74; Alexandre and Eisenhart 2013 WJLTA 287.

18 World Bank Working Paper No 146 27; Alexandre and Eisenhart 2013 WJLTA 287; Lawack 2013 WJLTA 319.

19 World Bank Working Paper No 146 27, 74; Alexandre and Eisenhart 2013 WJLTA 287; Lawack 2013 WJLTA 319.

20 It is submitted by the authors that mobile money providers in South Africa indeed take deposits from customers, in accordance with the definition of "deposit" as provided in $\mathrm{s} 1$ of the Banks Act 94 of 1990.

$21 \quad$ Alexandre and Eisenhart 2013 WJLTA 288; Lawack 2013 WJLTA 319. 
therefore finds itself at the crossroads of mobile technology and financial services ${ }^{22}$ and as such, it is a financial inclusion initiative which presents a uniquely sustainable, accessible solution to the problem that is financial exclusion. ${ }^{23}$ The reason why mobile money is so uniquely positioned to drive change in terms of financial inclusion is because the mobile phone is the most widely adopted form of modern technology in history. ${ }^{24}$ In 2006 the mobile phone became the first communications technology to have more users in third world countries than in first world countries. ${ }^{25}$ Today, almost half of the people in the world own a mobile phone. ${ }^{26}$ When comparing the number of people who have access to mobile phones with the number of people who do not have bank accounts, it becomes clear that there is a large overlap between these two groups worldwide: more than one billion individuals in developing markets have access to a mobile phone, but not to a bank account. ${ }^{27}$ Mobile technology offers novel alternatives to access financial services, ${ }^{28}$ since it is not subject to the restraints of infrastructure and high costs that have customarily prevented banks and other financial institutions from being accessible to the poor. ${ }^{29}$ Banks, mobile network operators (MNOs), and other non-bank institutions ${ }^{30}$ have subsequently developed methods to harness mobile technology in a manner which has effectively brought financial services within the grasp of unbanked, ${ }^{31}$ low-income individuals worldwide. ${ }^{32}$

\footnotetext{
Alexandre and Eisenhart 2013 WJLTA 288.

See eg GSMA 2015 http://www.m4dimpact.com/data/sectors/mobile-money-sector. GSMA 2015 http://www.m4dimpact.com/data/sectors/mobile-industry.

In 2006 more than $60 \%$ of all mobile phone subscribers were situated in developing countries. See World Bank Working Paper No 1468.

26 World Bank Working Paper No 146 vii.

27 GSMA 2015 http://www.m4dimpact.com/data/sectors/mobile-money-sector; Jenkins Developing Mobile Money Ecosystems 5; G20 Principles for Innovative Financial Inclusion (2010).

World Bank Working Paper No 146 xiii.

World Bank Working Paper No 146 vii.

30 Such as airtime sales agents, retailers and utility companies: Jenkins Developing Mobile Money Ecosystems 7.

31 This includes micro-entrepreneurs, low-income earners and the poor, according to Schoombee 2004 SAJE 581. According to Coetzee, characteristics of the unbanked in South Africa are that they typically do not have any form of transactional account, tend to be less well educated, reside in rural areas and townships, and lack a steady cash flow. A large proportion of the unbanked have no formal evidence of any form of credit history and are not banking product literate. See Coetzee 2009 SAJEMS 450. According to Lawack, "the unbanked" refers to individuals who do not have bank accounts and who do their "banking" through informal means. See Lawack 2013 WJLTA 317. 
What makes mobile money even more beneficial is the fact that mobile financial service systems can be integrated into pre-existing mobile network technology, which results in less infrastructural strain than traditional banking. ${ }^{33}$ This is especially true in cases where extensive prepaid mobile phone systems ${ }^{34}$ are already in place and can be utilised for mobile money. ${ }^{35}$ Mobile financial services are likely to expand as the market penetration of mobile technology increases. Indeed, mobile financial services have already developed to include services such as mobile finance, ${ }^{36}$ mobile banking ${ }^{37}$ and mobile payments. ${ }^{38}$

Mobile money is currently experiencing a revival in South Africa. An example of this is the recent re-launch of M-PESA. ${ }^{39} \mathrm{~A}$ large drive in the development of mobile money in South Africa is the objective of implementing policies which further financial inclusion while observing anti-money laundering ( $A M L)$ and countering the financing of terrorism (CFT) standards. ${ }^{40}$ It is submitted that the recent development in mobile money can also be attributed, at least in part, to the increasing market penetration level of mobile connections in South Africa. ${ }^{41}$ The market penetration for mobile connections in South Africa was $133 \%$ in $2013,{ }^{42}$ amounting to more than 70 million connections. ${ }^{43}$ Another reason for the recent revival of mobile money in South Africa could be the fact that South Africa still has a reasonably large rural population, estimated at $36 \%$ in 2013.44 As said previously, mobile money is specifically suitable to be implemented in areas where strong prepaid infrastructures

33 World Bank Working Paper No 1468 -9; Jenkins Developing Mobile Money Ecosystems 5.

34 In the mobile phone industry, "prepaid" refers to a type of mobile phone account that requires the purchase of call credit before services can be used. See Anon 2013 http://www.mobileburn.com/definition.jsp?term=pre-paid.

35 World Bank Working Paper No 146 8-9.

36 Which includes credit, insurance and savings: Lyons et al Sub-Saharan Africa Mobile Observatory 57.

37 Which can be divided into transactional and informational mobile banking: Lyons et al SubSaharan Africa Mobile Observatory 57.

38 Which includes person-to-person, government-to-person and business-to-business payments: Lyons et al Sub-Saharan Africa Mobile Observatory 57.

39 M-PESA was originally launched in South Africa in 2010 after the great success it achieved in Kenya, but did not achieve the same level of success in South Africa. See Goldstuck 2014 http://mg.co.za/article/2014-08-04-vodacom-re-launches-m-pesa-again.

$40 \quad$ World Bank Working Paper No 1464.

41 Lawack 2013 WJLTA 317.

42 GSMA 2015 http://www.m4dimpact.com/data/statistics/market-penetration-total-.

43 GSMA 2015 http://www.m4dimpact.com/data/statistics/number-of-connections-total.

44 World Bank 2015 http://data.worldbank.org/indicator/SP.RUR.TOTL.ZS/countries. 
already exist. South Africa is in a favourable position in this respect, having a large number of prepaid connections: $83.78 \%$ of the total number of mobile phone connections in South Africa was prepaid in $2013 .{ }^{45}$ South Africa is also a developing economy with a large sector of unbanked individuals and as such, the increasing amount of new payment products and services (NPPS) ${ }^{46}$ using mobile technology to expand access to the financial system holds great promise for financial inclusion. ${ }^{47}$ However, many of these initiatives are yet to reach scale. ${ }^{48}$

It is submitted that this can be partly due to challenges which have surfaced with respect to the effective application of AML/CFT measures to NPPS - specifically to mobile financial services. ${ }^{49}$ Concerns have been raised about the potential exploitation of mobile technology for illegal means. As already mentioned, mobile phones are used by billions of people around the world - inevitably including criminals and terrorists. ${ }^{50}$ Mobile money thus has inherent financial integrity ${ }^{51}$ risks, namely the risk of money laundering, terrorist financing, and the financing of a proliferation of weapons of mass destruction. ${ }^{52}$ Concerns also exist that mobile money could be detrimental to financial integrity as it increases the speed of transactions..$^{53}$ The regulation of mobile money, especially when issued by mobile

45 GSMA 2015 http://www.m4dimpact.com/data/statistics/connections-prepaid.

46 NPPS are new and innovative payment products and services that offer an alternative to traditional financial services. NPPS include a variety of products and services that involve new ways of initiating payments through, or extending the reach of, traditional retail electronic payment systems, as well as products that do not rely on traditional systems to transfer value between individuals or organisations. NPPS include, inter alia, prepaid cards, mobile payment services, and Internet-based payment services. FATF makes specific provision for the regulation of NPPS: FATF Guidance for a Risk-Based Approach: Prepaid Cards, Mobile Payments and Internet-Based Payment Services (2013) (hereafter referred to as FATF Guidance for a RiskBased Approach) para 3.

47 FATF Guidance: AML and Financial Inclusion para 30; FATF Guidance for a Risk-Based Approach para 3.

48 FATF Guidance: AML and Financial Inclusion para 30.

49 These challenges are created by the rapid development, increased functionality, and growing use of NPPS globally, and governments and private sector institutions have equally daunting tasks in ensuring that NPPS are not misused for money laundering and terrorist financing purposes. See FATF Guidance: AML and Financial Inclusion 30; FATF Guidance for a Risk-Based Approach 3.

$50 \quad$ World Bank Working Paper No 1462.

51 "Financial integrity" is the integrity of the financial system. Financial integrity is an interest which must be protected against certain threats or risks, which will be described below. See Van Duyne "Money Laundering Policy" 75.

52 Winn and De Koker 2013 WJLTA 156; World Bank Working Paper No 1462.

53 Alexandre and Eisenhart 2013 WJLTA 287. 
operators, is also a source of apprehension. ${ }^{54}$ While it is clear that mobile financial services can enhance the lives of many people in developing countries, the potential for abuse and the need for appropriate controls is something which cannot be ignored..$^{55}$

In this regard, the Financial Action Task Force (FATF) is presently focusing on the consequences that mobile money could possibly hold for financial integrity. South Africa is one of the 36 members of FATF - an inter-governmental body which develops and advances policies aimed at safeguarding the global financial system from financial integrity risks. ${ }^{56}$ The FATF Recommendations are observed by more than 180 countries, and are universally acknowledged as the international standard for AML/CFT. ${ }^{57}$ FATF's primary mandate is to see to it that financial integrity risks are addressed effectively. This includes the responsibility for ensuring that including more people in the financial system does not come at the expense of weakening effective AML/CFT measures. FATF does, however, concede that a so-called "overly cautious approach" to AML/CFT measures can inadvertently lead to the exclusion of legitimate individuals from the financial system. ${ }^{58}$ AML/CFT measures should therefore be designed in such a way that it does not prevent financially excluded and unbanked persons from having access to formal financial services. ${ }^{59}$

South Africa has been hailed as one of the foremost jurisdictions as far as financial inclusion is concerned, but while a supportive framework for mobile money has been developed, this framework is not fully inclusive. ${ }^{60}$ It would seem that while the market penetration level of mobile phones in South Africa is ever increasing, the regulatory framework for mobile financial services is, as Lawack puts it, "still not entirely conducive to greater financial inclusion". ${ }^{61}$

\footnotetext{
$54 \quad$ Alexandre and Eisenhart 2013 WJLTA 287.

55 De Koker 2013 WJLTA 195.

56 De Koker South African Money Laundering para 1.07; Financial Intelligence Centre Guidance Note 3A (hereafter "Guidance Note 3A"); FIC 2013 https://www.fic.gov.za/Download Content/NEWS/PRESSRELEASE/FIC\%20Annual\%20Report\%202012-13.pdf.

57 International Standards on Combating Money Laundering and the Financing of Terrorism and Proliferation: FATF Recommendations (2012) (hereafter FATF Recommendations) 7.

58 FATF Guidance for a Risk-Based Approach para 2.

59 FATF Guidance for a Risk-Based Approach para 3.

60 Winn and De Koker 2013 WJLTA 161.

61 Lawack 2013 WJLTA 317.
} 
From the above it is clear that mobile money presents great prospects for increased financial inclusion, since mobile phones are likely to become a common tool in performing financial transactions to a global extent in the not too distant future. ${ }^{62}$ However, since it is a daunting task to find equilibrium between financial integrity and financial inclusion, the expansion of access to financial services to impoverished South Africans could be hindered if rigid AML/CFT measures are not amended to make provision for wider financial inclusion. ${ }^{63}$ The question therefore is: how can the preservation of financial integrity and the promotion of financial inclusion be balanced in such a way that mobile money can be utilised and developed effectively, thereby promoting financial inclusion, without being detrimental to financial integrity? In answering this question, it is necessary to investigate what actual threats mobile money holds for financial integrity, and to what extent the potential of financial inclusion which mobile money holds is inhibited by AML regulations which are aimed at protecting financial integrity.

The purpose of this article will thus be to determine to what extent current $A M L$ regulations in South Africa make provision for the effective use of mobile money. This will be done firstly by examining the concept of mobile money and how it is regulated in South Africa. Thereafter, attention will be turned to money laundering and the current AML framework in South Africa. Finally, mobile money will be viewed in the light of the actual and perceived money laundering risks it poses and the question will be asked how this can be managed effectively.

The scope of the article will be narrowed down extensively due to space constraints. First, it must be noted that while money laundering and the financing of terrorism and proliferation usually go hand in hand, ${ }^{64}$ for the purposes of this article the focus will fall only on money laundering and not on the financing of terrorism. As far as mobile money is concerned, attention will be focused on mobile money as an independent method of payment or transfer only, and not on extended mobile financial service products such as mobile securities account services or mobile

World Bank Working Paper No 146 xiii.

De Koker South African Money Laundering para 1.06.

As is evident from instruments such as that of FATF and in academic works involving the topic of threats to financial integrity. 
banking. Furthermore, the discussion of the regulation of mobile money will be limited to the aspect of AML measures and not the general regulation of mobile money. ${ }^{65}$ The scope of the AML measures which will be discussed will be narrowed down to AML preventative measures, ${ }^{66}$ more specifically to customer due diligence $(C D D)^{67}$ only, with specific focus on the establishment and verification of the identities of clients as an AML measure.

Part 1 of this article will examine mobile money and the anti-money laundering framework in South Africa. In Part 2 of this article, the identification of clients will be looked at, after which customer due diligence, mobile money and a risk-based approach will be considered, before concluding with recommendations.

\section{$2 \quad$ Mobile money}

\subsection{Introduction}

Mobile money services are one of four main mobile financial services, the other three being mobile financial information services, mobile bank and securities accounts services, and mobile payment services. These services often work in parallel and in some circumstances one service operates as the basis for the others. The more a specific mobile financial service model deviates from traditional financial service models, the more its accompanying risks; but its likelihood for furthering financial inclusion also increases.68 Mobile financial services differ from other electronic financial services because the technology which is used for the former is flexible and usually easily accessible. ${ }^{69}$

65 General regulation will be discussed as far as it is pertinent to making certain determinations regarding mobile money, such as whether mobile money providers are financial service providers or not, in so far as it has bearing on AML measures.

66 Reference throughout this article to "AML measures" will mean "AML preventative measures", unless the context indicates otherwise.

67 Customer due diligence (CDD) is also referred to as "know your customer (KYC)". For the purposes of uniformity, the term CDD will be used throughout this article.

68 World Bank Working Paper No 146 xiii.

69 Compared, for example, to "Internet" or "online" banking, which requires an Internet connection and a computer: World Bank Working Paper No 1468. 


\subsection{A brief history of mobile money}

Mobile money as we know it today exists thanks to a so-called "evolutionary process" which commenced with the expansion of mobile technology across the globe almost two decades ago. ${ }^{70}$ This process can be divided into stages, the first of which can be associated with the inherent abilities of mobile phones in terms of data communication, which piqued the interest of banks and led them to launch mobile information services, after which the variety of services gradually started expanding to also include mobile banking and securities accounts. These services collectively became known as "mobile banking". ${ }^{71}$

The second stage can be associated with the increased expansion of mobile technology, which coincided with the advent of electronic money. This motivated experimentation with electronic money products of which the ability to initiate transactions through mobile phones was a fundamental design aspect. This stage also gave rise to the distribution network of agents 72 that function on a prepaid model. Non-banking institutions played an increasingly greater role because of this, as mobile money products and services are generally linked to prepaid accounts. MNOs in particular have been successful providers of mobile money services. ${ }^{73}$ Mobile financial services which are designed to facilitate an assortment of financial transactions by means of a mobile phone ${ }^{74}$ have seen the light of day in several emerging markets ${ }^{75}$ since 2005.

FATF Guidance for a Risk-Based Approach para 11.

FATF Guidance for a Risk-Based Approach para 11.

These agents are usually third parties or an entity who works for the mobile phone operator or bank: Aker and Mbiti $2010 \mathrm{~J}$ Econ Perspect 220-221.

73 FATF Guidance for a Risk-Based Approach para 11.

74 Including transmitting airtime, paying bills, and transferring money between individuals: Aker and Mbiti $2010 \mathrm{~J}$ Econ Perspect 220.

75 Defined by BusinessDictionary.com 2014 http://www.businessdictionary.com/definition/ emerging-markets.html\#ixzz3IzH3nPli as "new market structures arising from digitalisation, deregulation, globalisation, and open-standards, that are shifting the balance of economic power from the sellers to the buyers. In such markets information is freely and widely available, and is almost instantly accessible. To compete in these scenarios, a firm must adopt new processes based on information technologies, and must keep a close watch on the price, quality, and convenience trends". Also see Khanna and Palepu 2010 http://www.forbes.com/ 2010/05/27/winning-in-emerging-markets-opinions-book-excerpts-khanna-palepu.html. 
Today, mobile money services are enabled by traditional financial service providers ${ }^{76}$ and non-bank financial service providers ${ }^{77}$ alike, ${ }^{78}$ together with several different types of service providers as crucial partners, ${ }^{79}$ depending on the business model and technology which is employed. ${ }^{80}$ Mobile money is an ever-expanding service, and as such, it is continually furthering financial inclusion. ${ }^{81}$

\subsection{Nature and characteristics of mobile money ${ }^{82}$}

Mobile money services make provision for the use of mobile money or "m-money", 83 which is a form of electronic currency, ${ }^{84}$ or electronic money, ${ }^{85}$ the value of which is either stored on a mobile phone, or linked to a mobile phone account which clients obtain once they have been registered for mobile money services. ${ }^{86}$ Cash is thus converted into mobile money by depositing it into a mobile money account. ${ }^{87}$ This

76 Such as banks - see the definitions of "the business of a bank" and "deposit" in s 1 of the Banks Act 94 of 1990. A discussion of deposit-taking falls outside the scope of this article. Further see Perlman Legal and Regulatory Aspects 500 et seq; 658-661.

77 FATF Guidance for a Risk-Based Approach para 13. These non-bank financial service providers are labelled by FATF as money or value transfer services (MVTS).

78 FATF Guidance for a Risk-Based Approach para 13.

79 These partners include MNOs, and may include mobile telephone equipment manufacturers, telecommunications industry standards setting groups, payment networks, and software developers: FATF Guidance for a Risk-Based Approach para 13.

80 In terms of the technology used, business models use a range of approaches to facilitate mobile payments including text messaging, mobile Internet access, near field communication (NFC), programmed subscriber identity module (SIM) cards and unstructured supplementary service data (USSD). See FATF Guidance for a Risk-Based Approach para 13 for more detail.

81 See FATF Guidance for a Risk-Based Approach paras 12, 86.

82 A discussion of the legal nature of money falls outside the scope of this article. See Proctor Mann on the Legal Aspect of Money ch 1; Du Toit 2009 TSAR 3 et seq; Du Toit 2014 TSAR 806-809; Perlman Legal and Regulatory Aspects ch 3, 13.

83 For the sake of convenience and clarity, the term "mobile money" will be used throughout this article, rather than "m-money". Reference will also be made to "mobile payment systems" or "mobile payment services", since this is the terminology of choice used by FATF in the FATF Guidance For A Risk-Based Approach.

$84 \quad$ Alexandre and Eisenhart 2013 WJLTA 288; World Bank Working Paper No 14627.

85 See SARB Position Paper 3. According to the World Bank, electronic money is a stored-value or prepaid product in which a record of the funds or value available to the client for multipurpose use, including transfers to other users and conversion to and from cash, is stored on an electronic device in the client's possession. Common uses are phone credits and airtime as tender that users can trade for other goods and services. World Bank Working Paper No 14673. See also Du Toit 2014 TSAR 808. Also see Van Jaarsveld Aspects of Money Laundering 51-52.

86 World Bank Working Paper No 146 27, 74; Alexandre and Eisenhart 2013 WJLTA 287; Aker and Mbiti $2010 \mathrm{~J}$ Econ Perspect 220-221.

87 Alexandre and Eisenhart 2013 WJLTA 287, 288; Lawack 2013 WJLTA 319; World Bank Working Paper No 146 27, 74. 
stored value can be used to make payments or purchases ${ }^{88}$ or it can be sent to other mobile money users ${ }^{89}$ who can then store it on their own mobile phones and in turn use it to make payments or transfers. ${ }^{90}$ Mobile money can also be converted into cash by means of a "withdrawal". ${ }^{91}$ All of the above can be performed with minimal effort and expense ${ }^{92}$ through a network of local transfer agents. ${ }^{93}$ Mobile money comprises a primary account in its own right ${ }^{94}$ and no prior existence of a bank account is necessary for mobile money services to be activated. ${ }^{95}$ As such, mobile money makes it possible for clients to be financially linked by means of nothing more than a mobile phone.

An added benefit of mobile money is that it is exceptionally suitable for nonproximity situations, ${ }^{96}$ given the fact that it provides a platform for transactions to be effected by means of a technological medium which is unsurpassed in terms of

88 Which is either an over-the-counter service where an agent performs the transaction, or a socalled mobile wallet service where the client performs the transaction. See GSMA 2015 http://www.m4dimpact.com/analysis/impact-pathways/mobile-money.

89 Ie a mobile transfer of funds to a beneficiary takes place. This entails the transferring of money from person to person via so called mobile wallets or "m-wallets". Transfers can be recurrent, functioning as income support for the recipient, or used to send lump sums. See GSMA 2015 http://www.m4dimpact.com/analysis/impact-pathways/mobile-money.

90 World Bank Working Paper No 146 27; Alexandre and Eisenhart 2013 WJLTA 287; Lawack 2013 WJLTA 319.

91 World Bank Working Paper No 14627 . The withdrawal will be done via a local agent.

92 In general, each transaction will be subject to a transaction fee. See Aker and Mbiti $2010 \mathrm{~J}$ Econ Perspect 220-221. While this may seem counter-intuitive in the endeavour of providing affordable financial services to low-income individuals, it has been proven that clients are more willing to pay on a per transaction basis if they know that this will meet their needs, rather than having a "free" account which has various strict limitations and is ultimately of very little use, if any, to the client. See Alexandre and Eisenhart 2013 WJLTA 294-296 for more detail.

93 Alexandre and Eisenhart 2013 WJLTA 288; Lawack 2013 WJLTA 319. As previously stated, an agent is usually a third party or someone who works for the mobile phone operator or bank. The word "agent" in this sense should be construed as having the meaning of "distributor" and will usually be a retail outlet of sorts. See Aker and Mbiti $2010 \mathrm{~J}$ Econ Perspect 220-221; FATF Guidance for a Risk-Based Approach para 20.

$94 \quad$ Lawack 2013 WJLTA 319; World Bank Working Paper No 14674.

95 Alexandre and Eisenhart 2013 WJLTA 288; Lawack 2013 WJLTA 319. While not prevalent in South Africa, it is in fact possible for mobile money services to function completely independently of the banking system. In such instances, individuals can communicate directly with each other regarding payments and receipts and an accounting system for recording debits and credits operates autonomously, with no requirement for payments to be channelled through a central clearing system. This holds many advantages, such as the fact that payment is immediate and not subject to the delays of clearing systems; and it allows participants to receive immediate records of transactions that enhance trust in the conduct of the parties to a transaction and the organisation facilitating the transaction. See Klein and Mayer Mobile Banking 12.

In terms of clients being geographically far removed from both banks and their beneficiaries. 
mobility ${ }^{97}$ Mobile money is therefore accessible to all mobile phone users and can be especially valuable to unbanked individuals, since for many clients such a mobile money account will be the first account they have ever held..$^{98}$

While it is abundantly clear that mobile money services hold great financial inclusion potential, there are also other benefits linked to them. They could have an "overall positive impact on the economy" due to increased transaction speed and movement of money. ${ }^{99}$ Mobile money could also eventually reduce dependency on cash, as well as the amount of cash in the economy within which it is utilised. ${ }^{100}$ Payments by means of mobile money can furthermore contribute to promoting transparency, since electronic transactions are easier to trace than their cash counterparts. ${ }^{101}$ As stated in the Introduction, mobile money also plays an important role in supporting other economic sectors, ${ }^{102}$ especially in emerging markets. ${ }^{103}$ From the aforementioned it is clear that mobile money influences the advancement of financial services on several different levels. ${ }^{104}$

\subsection{Different mobile money business models today}

In order to address regulatory issues in terms of mobile money development and advancement, it is necessary to understand that the nature and operation of mobile money differs substantially from business model to business model, based on factors such as the service provider, which has the primary function, and the technical platform which is used. As previously mentioned, several different service providers can be involved in providing mobile money services, ${ }^{105}$ including banks, MNOs, agents, and electronic money issuers. ${ }^{106}$ These service providers have different

\footnotetext{
97 Alexandre and Eisenhart 2013 WJLTA 288-289.

98 Alexandre and Eisenhart 2013 WJLTA 288; Lawack 2013 WJLTA 319.

$99 \quad$ World Bank Working Paper No 14627.

100 Winn and De Koker 2013 WJLTA 159; World Bank Working Paper No 146 27. See Du Toit 2014 TSAR 811-815 for a discussion of the circumstances in which payment other than in "legal tender" (in terms of s 17 of the South African Reserve Bank Act 90 of 1989) may be accepted.

101 Lyons et al Sub-Saharan Africa Mobile Observatory 57.

102 Such as commerce, health insurance, and agricultural banking, among others. See Lyons et al Sub-Saharan Africa Mobile Observatory 57.

103 Lyons et al Sub-Saharan Africa Mobile Observatory 57.

104 Alexandre and Eisenhart 2013 WJLTA 288.

105 FATF Guidance for a Risk-Based Approach para 20.

106 MNOs provide the technical platform to allow access to the funds through a mobile phone, whereas distributors sell, or arrange for the issuance of funds on behalf of the issuer to clients.
} 
functions in different mobile money service business models, and one service provider may be responsible for more than one function. ${ }^{107}$

\subsubsection{The operator-centric model}

In the operator-centric model, an MNO acts autonomously in providing a mobile money service. ${ }^{108}$ This is often done by means of a mobile wallet which operates separately from the client's mobile account. ${ }^{109}$ The biggest challenge which MNOs face in terms of the operator-centric model is the fact that they are not connected to existing payment networks. This model has been launched in emerging markets by pioneers in the mobile financial services industry, but payments in terms of it are usually limited to transfers and so-called "airtime top-ups". ${ }^{110}$ MNOs usually offer mobile financial services under the operator-centric model with the intention of adding value to their existing core service, namely communication. Client funds are normally retained in a prepaid account by the MNO itself or by a subsidiary. Regardless of the fact that the MNO is the entity which bears the greatest financial risk and the active responsibility of offering the service under this model, it is standard practice in several jurisdictions for a partner bank to be the formal holder of the licence for the service. ${ }^{111}$

\subsubsection{The bank-centric model}

This model entails that a bank is the entity which offers mobile financial services to clients, with MNOs merely playing an assisting role and addressing quality concerns by means of experience. ${ }^{112}$ Under this model, clients become account holders of the

The electronic money issuer issues electronic money, which is described by FATF Guidance for $a$ Risk-Based Approach para 20 as "a record of funds or value available to a client stored on a payment device such as a chip on a prepaid card, mobile phones or on computer systems as a non-traditional account with a banking or non-banking entity". Further see Aker and Mbiti $2010 \mathrm{~J}$ Econ Perspect 220-221; Alexandre and Eisenhart 2013 WJLTA 287.

107 FATF Guidance for a Risk-Based Approach para 20. This description of business models is not exhaustive and does not describe any particular scheme, although reference to South African mobile money providers will be made where applicable in order to serve as concrete examples.

108 Chaix and Torre Different Models for Mobile Payments 4, 6.

109 Ie the mobile account containing prepaid credit or so-called "airtime".

110 Chaix and Torre Different Models for Mobile Payments 4, 10-14.

111 FATF Guidance for a Risk-Based Approach para 16.

112 Chaix and Torre Different Models for Mobile Payments 4, 10-14. 
bank which offers the mobile financial service. ${ }^{113}$ This must be distinguished from mobile banking, ${ }^{114}$ however, since under a bank-centric mobile money services model the bank either designs new products to provide for the needs of the previously unbanked, or alternatively provides electronic money that is not linked to a bank account. An MNO's function under this model is the mere provision of the mobile technology which facilitates the transactional messages. At no stage does the MNO manage or hold the client's funds. The MNO thus does not require a banking licence, since the bank is the financial service provider. ${ }^{115}$

\subsubsection{The peer-to-peer model}

The peer-to-peer model entails that a mobile financial service provider operates independently from financial institutions and MNOs in providing mobile money. ${ }^{116}$ Since this model is not prevalent in South Africa, it will not be discussed further.

\subsubsection{The collaboration model}

Several mobile financial services have been deployed by financial institutions and MNOs who have joined forces to establish agent networks to extend to geographical regions where financial exclusion is prevalent. ${ }^{117}$ This is known as the collaboration model, since it involves collaboration among banks, MNOs, and a third party connecting the bank and the MNO. ${ }^{118}$ In such instances, MNOs or other retail outlets offer services such as registering clients, taking deposits, and paying out cash to complete mobile money transactions. ${ }^{119}$ This model seems like the most viable model since it allows each partner to retain focus on his own separate skills, which makes it much easier to implement than any of the business models previously described. ${ }^{120}$ An example of this in South Africa is the recently re-launched M-PESA, a collaborative effort between Nedbank as bank and Vodacom as MNO. ${ }^{121}$

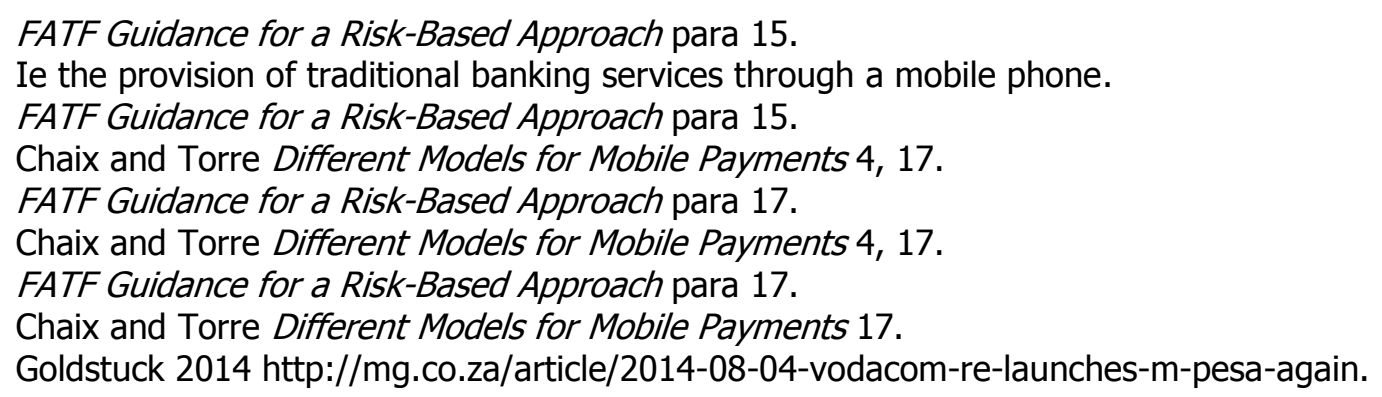


Although the above business models and the terminology that accompanies them may differ from jurisdiction to jurisdiction, it is assumed that in most mobile money business models the agent acts on behalf of a financial institution. ${ }^{122}$ The latter is accountable for the business relationship with the client. The agent is merely authorised by the financial institution to act on behalf of and under the control of the financial institution, thereby enabling the agent to deal with clients. The agent can also act on behalf of an MNO who is authorised to issue electronic money. ${ }^{123}$

\subsection{Regulation of mobile money in South Africa, with specific reference to AML measures}

All mobile financial service providers in South Africa are required to hold a banking licence. This legal requirement has the practical effect that MNOs become, in part, a division of a financial institution. MTN, for example, partially became a division of Standard Bank for the purposes of offering MTN MobileMoney. ${ }^{124}$

This would suggest that mobile money providers are indeed accountable institutions. ${ }^{125}$ However, since South Africa has no legal provisions expressly concerned with mobile money, ${ }^{126}$ refuge will be sought in the FATF Recommendations, which include any natural or legal person who conducts money or value transfer services (MVTS) as a business for or on behalf of a client in the definition of "financial institutions".127 "MVTS", in turn, are defined as:

... financial services that involve the acceptance of cash, cheques, other monetary instruments or other stores of value and the payment of a corresponding sum in cash or other form to a beneficiary by means of a communication, message, transfer, or through a clearing network to which the MVTS provider belongs.

122 FATF Guidance: AML and Financial Inclusion para 118; Interpretive Note 1 to FATF Recommendations 17.

123 FATF Guidance: AML and Financial Inclusion para 118.

124 World Bank Working Paper No 146 35. According to Standard Bank of South Africa Ltd v 3MFuture Africa (Pty) Ltd 2013 JDR 2748 (SCA), MTN and Standard Bank are equal owners of MTN MobileMoney. Incidentally, this is the only South African case to date (on appeal from $3 M$ Future Africa (Pty) Ltd v The Standard Bank of South Africa Ltd 2012 JDR 1716 (CP)) which contains the phrase "mobile money".

125 As per sch 1 of the Financial Intelligence Centre Act 38 of 2001 (hereafter "FICA").

126 It is submitted by Alexandre and Eisenhart 2013 WJLTA 297 that in terms of the "mobile" element, there is no need for specific "mobile money" regulation per se but instead for rules on electronic money that also apply to mobile money services.

127 FATF Methodology for Assessing Technical Compliance with the FATF Recommendations and the Effectiveness of AML/CFT Systems (2013) (hereafter FATF Methodology) Glossary 131-132. 
Transactions performed by such services can involve one or more intermediaries and a final payment to a third party, and may include any new payment methods. ${ }^{128}$

As such, mobile money providers fall within the scope of FATF's definition of a "financial institution" by virtue of the fact that they perform MVTS, and should therefore be subject to the AML measures imposed by the FATF Recommendations in general. ${ }^{129}$ FATF Recommendation 14 furthermore makes specific provision for MVTS by stating that providers of MVTS and their agents should be licensed or registered, ${ }^{130}$ and should show compliance with the relevant $A M L$ measures contained in the FATF Recommendations. ${ }^{131}$ FATF Recommendation 26 emphasises the fact that all financial service providers must be subject to regulation and supervision and specifically states that businesses providing MVTS should be licensed or registered, and "subject to effective systems for monitoring and ensuring compliance with national requirements to combat [money laundering]".132 Although Recommendation 26 does not specifically mention mobile financial services, ${ }^{133}$ it can be assumed that mobile financial service providers should be monitored, especially in the case where mobile money services are offered under a model other than the bank-centric business model, since poor oversight is a major risk factor in such instances. ${ }^{134}$

Of specific interest for the purposes of this article is the question of CDD. The "holding and management of an account" on behalf of a client is a circumstance which, according to FATF Recommendation 10, necessitates the performing of CDD measures. ${ }^{135}$ As has been seen, mobile money services entail the creation of an account, and mobile money service providers therefore "typically establish business

FATF Methodology Glossary 134.

FATF Guidance for a Risk-Based Approach paras 3, 34, 123.

130 Agents need not be registered if the MVTS provider maintains a current list of its agents which is accessible by competent authorities in the countries in which the MVTS provider and its agents operate (FATF Recommendations 14).

131 FATF Recommendations 14.

132 FATF Recommendations 26.

133 It is submitted that since the analysis of mobile money services has shown them to be a form of MVTS, such services are indeed included under FATF Recommendations 26.

134 World Bank Working Paper No 14640.

135 The reason for this is that the holding and managing of an account represent the establishment of a business relationship. 
relationships" with clients as envisaged by Recommendation $10^{136}$ - hence, CDD measures should be performed by mobile money service providers. The World Bank is also of the opinion that mobile money service providers should observe CDD measures just as other financial institutions do, including the verification of clients' identity when establishing business relations. ${ }^{137}$

The fact that multiple service providers are involved in providing mobile money services may, however, pose a problem for regulators in determining where "appropriate responsibility" for AML measures should be placed. ${ }^{138}$ The decision regarding which entity to hold responsible for imposing AML measures will be guided by the business model of the mobile money service. Under the bank-centric model the decision is easy: the bank should be subject to AML measures, seeing as it is a financial institution in any event. ${ }^{139}$ Under the operator-centric model, the MNO is the financial institution for the purposes of the FATF Recommendations, ${ }^{140}$ and should accordingly be obliged to observe AML measures.

Where there is more than one entity involved in the provision of mobile money (such as in the case of the collaboration model) and there is uncertainty as to which entity constitutes the actual provider, the following factors could aid in determining the appropriate entity. The actual provider should be: ${ }^{141}$

- $\quad$ the entity which visibly provides the service;

- $\quad$ the entity which manages client relationships;

- $\quad$ the entity which holds client funds; and

- the entity against which clients have a claim to their funds. ${ }^{142}$

Agents typically interact directly with clients, and are optimally suited to enforce AML preventative measures, such as CDD, on behalf of the provider. FATF views agents

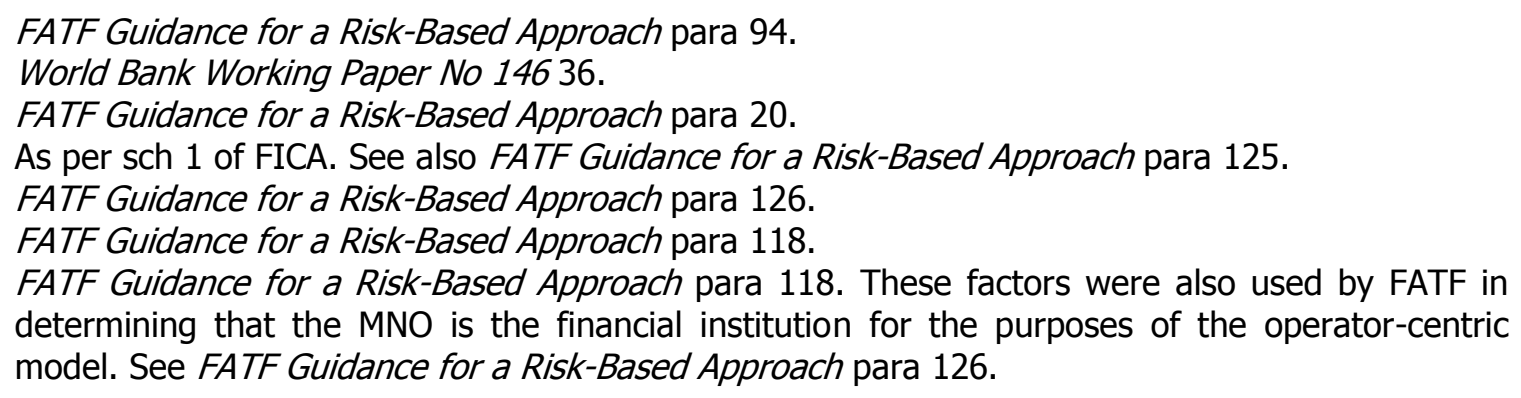
determining that the MNO is the financial institution for the purposes of the operator-centric model. See FATF Guidance for a Risk-Based Approach para 126. 
as mere extensions of the financial services provider, and as a result, the CDD conducted by agents is considered to be conducted by the financial institution. ${ }^{143}$

\section{Money laundering and the anti-money laundering framework in South Africa}

\subsection{What is money laundering?}

Money laundering is, in simple terms, the "conversion of criminal incomes into assets that cannot be traced back to the underlying crime". ${ }^{144}$ In other words, it entails the concealing of the nature, source, location or movement of the proceeds of crime so as to obscure the unlawfulness thereof in order for it to be used without arousing suspicion. ${ }^{145}$ "Proceeds of crime" includes any asset, cash or otherwise, which is acquired by means of the commission of any criminal offence. ${ }^{146}$ The objective of money laundering is thus to conceal the proceeds of crime in order for the offender to circumvent prosecution ${ }^{147}$ whilst being able to utilise as much of the said proceeds of crime as possible. ${ }^{148}$

Money laundering is conventionally divided into three stages, namely placement, layering, and integration. ${ }^{149}$ Placement is the first stage in the process and comprises the displacement of funds obtained by means of illegal activities to a location or in a form that is less suspicious to law enforcement authorities and more expedient to the criminal offender. ${ }^{150}$ Once that has been done, the proceeds are channelled into financial institutions or the retail economy. The second phase is layering. This entails

143 FATF Guidance for a Risk-Based Approach para 127; FATF Guidance: AML and Financial Inclusion para 119. In this regard, "agents" or distributors are also acting as "agents" in the legal sense of the word, ie as entities with the agency to act on behalf of a person (natural or juristic), in this case the financial services provider.

144 Reuter and Truman Chasing Dirty Money 1. Also see De Koker South African Money Laundering para 1.02.

145 Reuter and Truman Chasing Dirty Money 25; Van Jaarsveld Aspects of Money Laundering 619620.

146 Typical criminal activities in which money laundering is involved include theft, robbery, fraud, abduction, extortion, drug dealing, tax evasion, and the like. See Reuter and Truman Chasing Dirty Money 25.

147 Prosecution in terms of the predicate crime, the definition of which will be discussed shortly.

148 Financial Intelligence Centre Guidance Note 3A: Guidance for Accountable Institutions on Client Identification and Verification and Related Matters (28 March 2013) (Guidance Note 3A).

149 De Koker South African Money Laundering para 1.04; Van Jaarsveld Aspects of Money Laundering 620.

150 De Koker South African Money Laundering para 1.04. 
the severance of proceeds from their unlawful origin by making use of several intricate financial transactions to obscure the audit trail and conceal the proceeds, usually by passing such proceeds through various institutions and jurisdictions in order to disguise the origin thereof. ${ }^{151}$ The final stage in the process is incorporation into an economy, during which unlawful proceeds are converted into seemingly lawful business earnings by means of ordinary financial or commercial operations. ${ }^{152}$ Money laundering is criminalised in South Africa by the Prevention of Organised Crime Act 121 of 1998.

Typical money laundering methods which are pertinent to this discussion are structuring and EFTs. ${ }^{153}$ Structuring, also known as "smurfing", entails the splitting of a large financial transaction into several smaller transactions. This is typically done by dividing cash deposits into amounts below a minimum limit above which banks are required to report financial transactions, known as threshold amounts. Couriers or so-called "smurfs" then make these deposits into several different bank accounts, often at different banks. ${ }^{154}$ This is done in order to avoid detection by authorities. ${ }^{155}$ EFTs are also prime tools for laundering money. This transaction entails the transferring of the control of funds from one institution ${ }^{156}$ to another by sending a notification electronically. ${ }^{157}$ Such transfers are especially popular in the layering stage, since funds can be transferred through various different institutions in different jurisdictions in order to obscure the trail to the origin of the funds. Transfers can also be made from several different bank accounts into which deposits

151 De Koker South African Money Laundering para 1.04.

152 Reuter and Truman Chasing Dirty Money 25. Evidence proposes that money laundering is generally not practised as a separate activity by professionals, but is usually part of the underlying offence, which is known as the "predicate crime", or involves ad hoc assistance. Such assistance is criminalised in South Africa by s 5 of the Prevention of Organised Crime Act 121 of 1998 (hereafter "POCA"). See further Reuter and Truman Chasing Dirty Money 4-5.

153 This discussion will be limited to these methods only. The reason for this specific demarcation will become apparent below, where it will be explained how and why these two methods of money laundering are of specific importance when dealing with mobile money and the regulation thereof.

154 De Koker South African Money Laundering para 1.04.

155 Reuter and Truman Chasing Dirty Money 30; World Bank Working Paper No 14612.

156 Usually a bank.

157 Reuter and Truman Chasing Dirty Money 30. Also see Van Jaarsveld Aspects of Money Laundering 52-55 for a discussion of the nature of EFTs and 623-624 regarding how EFTs are utilised by money launderers. 
have been made by "smurfing" to a single collecting account, which will usually be located abroad in an offshore financial centre. ${ }^{158}$

\subsection{Anti-money laundering measures in South Africa}

The South African legislator has made provision for comprehensive AML regulation in two acts: the Prevention of Organised Crime Act 121 of 1998 (POCA) and the Financial Intelligence Centre Act 38 of 2001 (FICA). ${ }^{159}$ POCA is the main legislative measure in terms of demarcating conduct that constitutes money laundering offences, but it does not provide for the measures which should be implemented in order to suppress and detect money laundering. These measures are provided for in FICA, which is the primary legislative instrument concerned with prescribing AML measures. ${ }^{160}$ In other words, POCA outlines activities that constitute money laundering offences, ${ }^{161}$ while FICA prescribes the measures to be implemented to suppress and detect money laundering. ${ }^{162}$

Anti-money laundering regimes have two pillars: prevention ${ }^{163}$ and enforcement. ${ }^{164}$ The present article will focus on the prevention pillar, with specific reference to $\mathrm{CDD}^{165}$ as a preventative measure in terms of the FATF Recommendations ${ }^{166}$ and the above-mentioned South African legislation.

\footnotetext{
158 Reuter and Truman Chasing Dirty Money 30.

159 De Koker South African Money Laundering para 3.01; Van Jaarsveld Aspects of Money Laundering 636.

160 De Koker South African Money Laundering para 7.01; Lawack 2013 WJLTA 331.

161 De Koker South African Money Laundering para 2.04; Lawack 2013 WJLTA 331.

162 De Koker South African Money Laundering 2.07 and 7.01. Also see Lawack 2013 WJLTA 331. Focus in this regard will fall primarily on FICA.

163 This pillar comprises the following measures: CDD, reporting, regulation and supervision, and sanctions. See Reuter and Truman Chasing Dirty Money 4.

164 This pillar includes measures such as a list of predicate crimes, investigation, prosecution and punishment, and confiscation. See Reuter and Truman Chasing Dirty Money 4.

165 According to the World Bank, customer due diligence entails the following: "Processes that include verifying a customer's identity and assessing the risks associated with that customer which enable the financial institution or another entity to predict with relative certainty the types of transactions in which a customer is likely to engage. These processes assist the bank in determining when transactions are potentially suspicious." See World Bank Working Paper No 14673.

166 For ease of reference and to avoid confusion, reference to the instrument as such will be to FATF Recommendations and will be done in terms of page numbers of the document, whereas reference to a specific Recommendation will be done in terms of the number of the Recommendation in question.
} 


\subsubsection{The Financial Action Task Force Recommendations}

The Financial Action Task Force (FATF) is the intergovernmental global AML and counter-terrorist financing (CFT) standard-setting body: 167 "The FATF Recommendations are recognised as the global anti-money laundering ( $A M L)$ and counter-terrorist financing (CFT) standard." 168 FATF thus develops guidance and best practices $^{169}$ to assist jurisdictions in the application of international AML standards, mainly by improving a country's existing AML regime. ${ }^{170}$ The FATF Recommendations set out a comprehensive and consistent framework of measures which jurisdictions are advised to implement in order to combat money laundering. ${ }^{171}$ It is therefore advisable that authorities as well as private sector institutions apply the FATF Recommendations as far as it may be relevant. ${ }^{172}$

South Africa is a member of FATF ${ }^{173}$ and as such, the South African Financial Intelligence Centre (FIC) regularly publishes FATF policies. ${ }^{174}$ It should be noted that such policies are neither legislative instruments nor formal guidance issued under FICA. ${ }^{175}$ However, FICA was amended in 2008 by the Financial Intelligence Centre Amendment Act 11 of 2008, which addressed, inter alia, some of the supervisory concerns raised in the FATF mutual evaluation of South Africa in 2008. ${ }^{176}$ This is a clear indicator that the FATF Recommendations do carry weight and have a large influence on South Africa's AML policies. Guidance Note $3 \mathrm{~A}$, issued by the FIC in 2013, reiterates this by stating that the FATF Recommendations form the contextual

167 De Koker South African Money Laundering para 1.07; De Koker 2013 WJLTA 165.

168 FATF Recommendations preamble.

169 In the form of the FATF Recommendations.

170 FIC 2008 https://www.fic.gov.za/SiteContent/ContentPage.aspx?id=115.

171 FATF Recommendations 7.

172 FATF Recommendations 7; FIC 2008 https://www.fic.gov.za/SiteContent/ContentPage. aspx?id $=115$.

173 World Bank Working Paper No 146 4; FIC 2013 https://www.fic.gov.za/DownloadContent/ NEWS/PRESSRELEASE/FIC\%20Annual\%20Report \%202012-13.pdf.

174 De Koker South African Money Laundering para 5.12.

175 See FIC 2008 https://www.fic.gov.za/SiteContent/ContentPage.aspx?id=115.

176 Lawack 2013 WJLTA 331. The FATF Mutual Evaluation was based on the laws, regulations and other materials supplied by South Africa, and information obtained by the evaluation team during its onsite visit to South Africa from 4-15 August 2008, and subsequently. During the evaluation, the team met with officials and representatives of all relevant South African government agencies and the private sector. For more information, see the FATF GAFI Mutual Evaluation Report: Anti-Money Laundering and Combating the Financing of Terrorism, South Africa (2009) (hereafter FATF GAFI MER). Also see De Koker South African Money Laundering paras 1.04 and 2.10 regarding the mutual evaluation process and outcomes. 
basis for the implementation of FICA and that international standards such as the FATF Recommendations provide the minimum requirements with which countries must comply. ${ }^{177}$

The relevant provisions of POCA and FICA will accordingly be discussed with reference to the FATF Recommendations and, where applicable, in terms of its compliance with the FATF Recommendations as described in the FATF Methodology. ${ }^{178}$

\subsubsection{Prevention of Organised Crime Act 121 of 1998}

According to FATF Recommendation 3, money laundering should be criminalised on the basis of the United Nations Convention against Illicit Traffic in Narcotic Drugs and Psychotropic Substances (1988) (Vienna Convention) and the United Nations Convention against Transnational Organised Crime (2000) (Palermo Convention). As a point of departure, it should be noted that South Africa has ratified both the Vienna Convention and the Palermo Convention. ${ }^{179}$

Furthermore, according to FATF Recommendation 3, the crime of money laundering should be applied to all serious offences in order to include the widest range of predicate offences. As previously said, POCA is the primary piece of South African legislation in terms of outlining activities that constitute offences relating to money

177 Guidance Note $3 A$ para 24.

178 The FATF Methodology prescribes how countries should go about assessing technical compliance with the FATF Recommendations and the effectiveness of AML/CFT systems. The key points in this regard is that all requirements for financial institutions should be introduced either in law (any legislation issued or approved through a parliamentary process or other equivalent means provided for under the country's constitutional framework, which imposes mandatory requirements with sanctions for noncompliance, as well as judicial decisions that impose relevant requirements, and which are binding and authoritative in all parts of the country) or enforceable means (regulations, guidelines, instructions or other documents or mechanisms that set out enforceable AML/CFT requirements in mandatory language with sanctions for non-compliance, and which are issued or approved by a competent authority) and that sanctions for noncompliance should be effective, proportionate and dissuasive. It should also be clear that these sanctions will be applied in the event of non-compliance by a financial institution. For a complete list of the factors to be taken into account when assessing whether a document or mechanism has requirements that amount to enforceable means, see FATF Methodology 123 and the note on the Legal Basis of Requirements on Financial Institutions and DNFBPS contained in the FATF Recommendations.

179 United Nations Convention against Illicit Traffic in Narcotic Drugs and Psychotropic Substances (1988) (Vienna Convention); United Nations Convention against Transnational Organised Crime (2000) (Palermo Convention). 
laundering. ${ }^{180}$ This is also confirmed in the definition of "money laundering" or "money laundering activity" in FICA. ${ }^{181}$

POCA criminalises money laundering in conformity with the requirements of the Vienna Convention and the Palermo Convention, ${ }^{182}$ and as such it is compliant with the first part of FATF Recommendation number 3. POCA makes provision for the conversion or transfer, concealment or disguise, possession, and acquisition of property ${ }^{183}$ and criminalises the act of money laundering in section $4 .{ }^{184}$ Sections 5 and 6 of POCA furthermore provide that assisting another to benefit from proceeds of unlawful activities, as well as the acquisition, possession or use of proceeds of unlawful activities, constitute offences. ${ }^{185}$

As can be seen, proceeds from "unlawful activities"186 are included in all these sections, clearly meeting the requirement set out in the second part of FATF Recommendation 3, namely that the crime of money laundering should be applied to all serious offences, with a view to including the widest range of predicate offences. The fact that money laundering is a serious offence under South African law can be inferred from the maximum sentences one can incur for being convicted thereof: either a fine of up to R100 million, or imprisonment for up to 30 years. ${ }^{187}$

\subsubsection{Financial Intelligence Centre Act 38 of $2001^{188}$}

As mentioned previously, South African legislation not only proscribes conduct that constitutes money laundering, but also makes provision for various control measures which have the objective of enabling the suppression, detection and investigation of money laundering. ${ }^{189}$ These control measures can be found in FICA, which is the

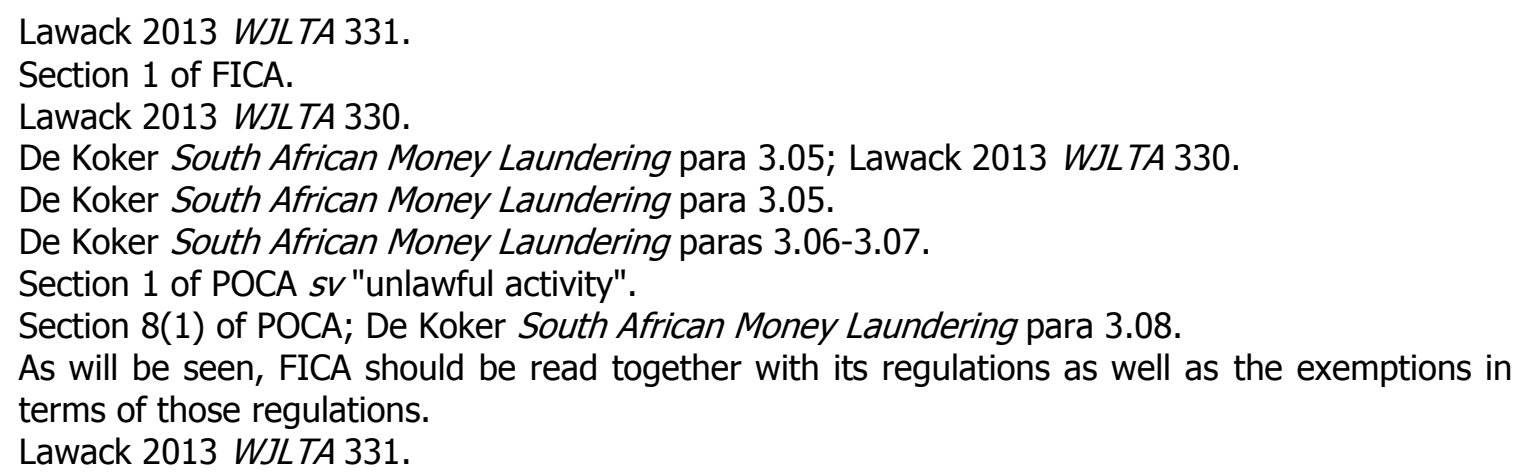


principal source of legislation concerned with outlining AML measures. ${ }^{190}$ These measures are based on three basic principles ${ }^{191}$ of money laundering detection and investigation, namely that intermediaries in the financial system must know whom they are doing business with, record must be kept of transactions through the financial system, and transactions which could possibly involve money laundering must be reported to the investigating authorities. ${ }^{192}$

The control measures enacted by FICA include stipulations to the effect that institutions ${ }^{193}$ need to establish and verify the identities of their clients, ${ }^{194}$ keep certain records, report certain information and implement measures that will assist in compliance with FICA. ${ }^{195}$ Section 77 of FICA also confers power upon the Minister of Finance to make regulations in terms of the Act, which will have legislative authority equal to that of FICA itself. ${ }^{196}$ As a result, FICA is to be read together with the Money Laundering and Terrorist Financing Control Regulations (MLTFC Regulations), ${ }^{197}$ as well as several Exemptions in terms of FICA. ${ }^{198}$ The application of these measures has led to the implementation of comprehensive AML policies and preventative measures in South Africa. ${ }^{199}$

Besides enacting AML regulations, FICA also established the FIC as the institution tasked with the collection, analysis and disclosure of data to aid the detection, prevention and deterrence of money laundering in South Africa. ${ }^{200}$ Section 4(c) of FICA authorises the FIC to issue guidance regarding various matters concerned with

190 See Lawack 2013 WJLTA 331.

191 For the purposes of the present discussion, only the first of these three principles will be of relevance.

192 FIC 2008 https://www.fic.gov.za/SiteContent/ContentPage.aspx?id=115.

193 Most of the obligations imposed by FICA are applicable to "accountable institutions". These are institutions that fall within any one of the categories of institutions listed in sch 1 to FICA. For the purposes of the present discussion, focus will fall purely on specific control measures. These control measures will be placed within the context of mobile money in para 5 below.

194 As stated in the Introduction, this is the specific AML measure which will be scrutinised in this article. Whilst the FATF prefers to use the term "customer", FICA makes use of the term "client". The term "client" will forthwith be used for the sake of uniformity.

195 Guidance Note $3 A$.

196 According to s 1 of FICA, any reference in the Act to the Act will include any regulations under the Act in terms of $\mathrm{s} 77$.

197 GN R1595 in GG 24176 of 20 December 2002.

198 The Exemptions are to be found in the Schedule to GN R1595 in GG 24176 of 20 December 2002 and in GN R1353 and R1354 in GG 27011 of 19 November 2004.

199 Lawack 2013 WJLTA 331.

200 De Koker South African Money Laundering para 5.02. See also ss 2, 3 and 4 of FICA. 
compliance in terms of the obligations imposed by FICA. ${ }^{201}$ The MLTFC Regulations also make provision for guidance notes under Regulation 28(1).

The establishment of the FIC in terms of section 2 of FICA and the powers it has in terms of Regulation 28(1) illustrate compliance with FATF Recommendation 2, which states that "countries should have national AML/CFT policies ... which should be regularly reviewed, and should designate an authority ... that is responsible for such policies". 202 It should be noted that the only form of guidance officially recognised in terms of FICA and the Regulations is guidance which is imparted by the FIC. As such, guidance provided by the FIC is authoritative in nature. An accountable institution must apply guidance issued by the FIC, or demonstrate an equivalent level of compliance with the relevant obligations under FICA. ${ }^{203}$ Enforcement action may stem from non-compliance with FICA where an accountable institution does not follow guidance issued by the FIC and cannot demonstrate compliance with the legal obligation to which the guidance relates. ${ }^{204}$

Section 21 of FICA 205 specifically deals with control measures for money laundering, including the establishment and verification of clients' identities. In Part 2 of this article, this will, accordingly, be discussed in greater detail.

Guidance Note $3 A$.

Own emphasis added.

Guidance Note $3 A$ para 2, own emphasis added.

Guidance Note $3 A$ para 2.

See ss $21-45$ of FICA. 


\section{BIBLIOGRAPHY}

\section{Literature}

Aker and Mbiti $2010 \mathrm{~J}$ Econ Perspect

Aker JC and Mbiti IM "Mobile Phones and Economic Development in Africa" $2010 \mathrm{~J}$ Econ Perspect 207-232

Alexandre and Eisenhart 2013 WJLTA

Alexandre C and Eisenhart LC "Mobile Money as an Engine of Financial Inclusion and Lynchpin of Financial Integrity" 2013 WJLTA 285-302

Chaix and Torre Different Models for Mobile Payments

Chaix L and Torre D Different Models for Mobile Payments (University of Nice Sophia-Antipolis 2010)

Chatain et al World Bank Working Paper No 146

Chatain P et al World Bank Working Paper No 146: Integrity in Mobile Phone Financial Services: Measures for Mitigating Risks from Money Laundering and Terrorist Financing (World Bank New York 2008)

Coetzee 2009 SAJEMS

Coetzee J "Personal or Remote Interaction? Banking the Unbanked in South Africa" 2009 SAJEMS 448-461

De Koker 2011 JFC

De Koker L "Aligning Anti-money Laundering, Combating of Financing of Terror and Financial Inclusion: Questions to Consider when FATF Standards are Clarified" 2011 JFC 361-386

De Koker 2013 WJLTA

De Koker L "The 2012 Revised FATF Recommendations: Assessing and Mitigating Mobile Money Integrity Risks Within the New Standards Framework" 2013 WJLTA 165-196 
De Koker South African Money Laundering

De Koker L South African Money Laundering and Terror Financing Law (LexisNexis Durban 2014)

Du Toit 2009 TSAR

Du Toit SF "Die Dematerialisasie van Geld: In die Skadu van die Sakereg" 2009 TSAR 1-21

Du Toit 2014 TSAR

Du Toit SF "Die Kwynende Belang van die Begrip 'Wettige Betaalmiddel' Binne 'n Vinnig Veranderende Betalingslandskap" 2014 TSAR 805-816

Gurusamy Financial Services

Gurusamy S Financial Services and Systems $2^{\text {nd }}$ ed (Tata McGraw-Hill Education New Delhi 2009)

Jenkins Developing Mobile Money Ecosystems

Jenkins B Developing Mobile Money Ecosystems (International Finance Corporation and the Harvard Kennedy School Washington DC 2008)

Jobodwana 2009 JICLT

Jobodwana ZN "E-Commerce and Mobile Commerce in South Africa: Regulatory Challenges" 2009 JICLT 287-298

Klein and Mayer Mobile Banking

Klein M and Mayer C Mobile Banking and Financial Inclusion: The Regulatory Lessons (Frankfurt School of Finance and Management Frankfurt 2011)

Lawack 2013 WJLTA

Lawack VA "Mobile Money, Financial Inclusion and Financial Integrity: The South African Case" 2013 WJLTA 317-346

Lyons et al Sub-Saharan Africa Mobile Observatory

Lyons P et al Sub-Saharan Africa Mobile Observatory 2012 (Deloitte and GSMA London 2012) 
O'Sullivan and Sheffrin Economics

O'Sullivan A and Sheffrin SM Economics: Principles in Action (Prentice Hall Needham MA 2003)

Perlman Legal and Regulatory Aspects

Perlman LJ Legal and Regulatory Aspects of Mobile Financial Services (LLDthesis University of South Africa 2012)

Proctor Mann on the Legal Aspect of Money

Proctor C Mann on the Legal Aspect of Money $7^{\text {th }}$ ed (Oxford University Press Oxford 2012)

Reuter and Truman Chasing Dirty Money

Reuter $\mathrm{P}$ and Truman EM Chasing Dirty Money: The Fight against Money Laundering (Institute for International Economics Washington DC 2004)

SARB Position Paper

South African Reserve Bank National Payment System Department Position Paper on Electronic Money NPS 01/2009 (SARB Johannesburg 2009)

Schoombee 2004 SAJE

Schoombee A "South African Banks and the Unbanked: Progress and Prospects" 2004 SAJE 581-603

Van Duyne "Money Laundering Policy"

Van Duyne PC "Money Laundering Policy: Fears and Facts" in Van Duyne PC, Von Lampe $\mathrm{K}$ and Newell JL (eds) Criminal Finances and Organising Crime in Europe (Wolf Nijmegen 2003) 67-104

Van Jaarsveld Aspects of Money Laundering

Van Jaarsveld IL Aspects of Money Laundering in South African Law (LLDthesis University of South Africa 2011) 
Winn and De Koker 2013 WJLTA

Winn JK and De Koker L "Introduction to Mobile Money in Developing Countries: Financial Inclusion and Financial Integrity Conference Special Issue" 2013 WJLTA 155-164

\section{Case law}

3M Future Africa (Pty) Ltd v The Standard Bank of South Africa Ltd 2012 JDR 1716 (CP)

Standard Bank of South Africa Ltd v 3MFuture Africa (Pty) Ltd 2013 JDR 2748 (SCA)

\section{Legislation}

Banks Act 94 of 1990

Financial Intelligence Centre Act 38 of 2001

Financial Intelligence Centre Amendment Act 11 of 2008

Prevention of Organised Crime Act 121 of 1998

South African Reserve Bank Act 90 of 1989

\section{Government publications}

Financial Intelligence Centre Guidance Note 3A: Guidance for Accountable Institutions on Client Identification and Verification and Related Matters (28 March 2013) (Guidance Note 3A)

GN R1595 in GG 24176 of 20 December 2002

GN R1353 in GG 27011 of 19 November 2004 (Money Laundering and Terrorist Financing Control Regulations)

\section{International instruments}

FATF GAFI MER

FATF GAFI Mutual Evaluation Report: Anti-Money Laundering and Combating the Financing of Terrorism, South Africa (2009) 
FATF Guidance: AML and Financial Inclusion

FATF Guidance: Anti-Money Laundering and Terrorist Financing Measures and Financial Inclusion (2013)

FATF Guidance for a Risk-Based Approach

FATF Guidance for a Risk-Based Approach: Prepaid Cards, Mobile Payments and Internet-Based Payment Services (2013)

FATF Methodology

FATF Methodology for Assessing Technical Compliance with the FATF Recommendations and the Effectiveness of AML/CFT Systems (2013)

FATF Recommendations

International Standards on Combating Money Laundering and the Financing of Terrorism and Proliferation: FATF Recommendations (2012)

G20 Principles for Innovative Financial Inclusion

G20 Principles for Innovative Financial Inclusion (2010)

Palermo Convention (2000)

United Nations Convention against Transnational Organised Crime (2000)

Vienna Convention (1988)

United Nations Convention against Illicit Traffic in Narcotic Drugs and Psychotropic Substances (1988)

\section{Internet sources}

Anon 2013 http://www.mobileburn.com/definition.jsp?term=pre-paid Anon 2013 What is "Prepaid"? http://www.mobileburn.com/definition.jsp? term=pre-paid accessed 9 May 2013

BusinessDictionary.com $2014 \quad$ http://www.businessdictionary.com/definition/ emerging-markets.html\#ixzz3IzH3nPli 
BusinessDictionary.com $2014 \quad$ Emerging Markets

http://www.businessdictionary.com/definition/emerging-

markets.html\#ixzz3IzH3nPli accessed 9 May 2013

BusinessDictionary.com

2014

http://www.businessdictionary.com/definition/financialservices.html\#ixzz3I5S dfxj7

BusinessDictionary.com 2014 Financial Services http://www.business dictionary.com/definition/financialservices.html\#ixzz3I5Sdfxj7 accessed 9 May 2013

FIC 2008 https://www.fic.gov.za/SiteContent/ContentPage.aspx?id=115

Financial Intelligence Centre 2008 Financial Action Task Force https://www.fic.gov.za/SiteContent/ContentPage.aspx?id=115 accessed 9 May 2013

FIC $2013 \quad$ https://www.fic.gov.za/DownloadContent/NEWS/PRESSRELEASE/ FIC\%20Annual\%20Report\%202012-13.pdf

Financial Intelligence Centre 2013 Financial Intelligence Centre Annual Report 2012/13

https://www.fic.gov.za/DownloadContent/NEWS/PRESSRELEASE/FIC\%20Ann ual\%20Report\%202012-13.pdf accessed 7 August 2014

Goldstuck 2014 http://mg.co.za/article/2014-08-04-vodacom-re-launches-m-pesaagain

Goldstuck A 2014 Vodacom Re-launches M-pesa (Again) http://mg.co.za/article/2014-08-04-vodacom-re-launches-m-pesa-again accessed 7 August 2014

GSMA 2015 http://www.m4dimpact.com/analysis/impact-pathways/mobile-money GSMA 2015 Overview of Mobile Money http://www.m4dimpact.com /analysis/impact-pathways/mobile-money accessed 28 June 2015 
GSMA 2015 http://www.m4dimpact.com/data/sectors/mobile-industry GSMA 2015 Mobile Industry http://www.m4dimpact.com/data/sectors/mobileindustry accessed 28 June 2015

GSMA 2015 http://www.m4dimpact.com/data/sectors/mobile-money-sector GSMA 2015 Mobile Money Sector http://www.m4dimpact.com/data/sectors/mobile-money-sector accessed 28 June 2015

GMSA 2015 http://www.m4dimpact.com/data/statistics/connections-prepaid GSMA 2015 Connections - Prepaid http://www.m4dimpact.com/data/statistics /connections-prepaid accessed 28 June 2015

GMSA 2015 http://www.m4dimpact.com/data/statistics/market-penetration-totalGSMA 2015 Market Penetration, Total (\%) http://www.m4dimpact.com/data /statistics/market-penetration-total- accessed 28 June 2015

GMSA 2015 http://www.m4dimpact.com/data/statistics/number-of-connections-total GSMA 2015 Number of Connections Total http://www.m4dimpact.com/data /statistics/number-of-connections-total accessed 28 June 2015

Khanna and Palepu 2010 http://www.forbes.com/2010/05/27/winning-in-emergingmarkets-opinions-book-excerpts-khanna-palepu.html Khanna T and Palepu KG 2010 How to Define Emerging Markets http://www.forbes.com/2010/05/27/winning-in-emerging-markets-opinionsbook-excerpts-khanna-palepu.html accessed 30 June 2014

World Bank 2015 http://data.worldbank.org/indicator/SP.RUR.TOTL.ZS/countries World Bank 2015 Rural Population (\% of Total Population) http://data.worldbank.org/indicator/SP.RUR.TOTL.ZS/countries accessed 28 June 2015 


\section{LIST OF ABBREVIATIONS}

AML

ATM

CDD

CFT

DNFBPS

EFT

FATF

FIC

FICA

GSMA

J Econ Perspect

JFC

JICLT

KYC

MLTFC

MNO

MVTS

NFC

NPPS

POCA

SAJE

SAJEMS

SARB

SIM

TSAR

USSD

WJLTA
Anti-money laundering

Automated teller machine

Customer due diligence

Countering the financing of terrorism

Electronic funds transfer

Financial Action Task Force

Financial Intelligence Centre

Financial Intelligence Centre Act

Groupe Speciale Mobile Association

Journal of Economic Perspectives

Journal of Financial Crime

Journal of International Commercial Law and Technology

Know your customer

Money laundering and terrorist financing control

Mobile network operator

Money or value transfer services

Near field communication

New payment products and services

Prevention of Organised Crime Act

South African Journal of Economics

South African Journal of Economic and Management Sciences

South African Reserve Bank

Subscriber Identity Module

Tydskrif vir die Suid-Afrikaanse Reg

Unstructured supplementary service data

Washington Journal of Law, Technology and Arts 